\title{
電力貯蔵装置を備えた電力系統における太陽光発電 システムの経済性評価
}

$\begin{array}{llllll}\text { 正 員 } & \text { 西 } & \text { 川 } & \text { 禕 } & \text { 一 } & \text { (京都大) } \\ \text { 正員 } & \text { 手 } & \text { 塚 } & \text { 哲 } & \text { 央 } & \text { (京都大) } \\ \text { 非会員 } & \text { 喜 } & \text { 多 } & & \text { 一 } & \text { (京都大) } \\ \text { 非会員 } & \text { 姜 } & & \text { 文 } & \text { 盛 } & \text { (京都大) }\end{array}$

Economic Evaluation of a Photovoltaic Power Generation System introduced into the Electric Power System with a Storage Battery

Yoshikazu Nishikawa, Member, Tetsuo Tezuka, Member, Hajime Kita, Non-member, Moon-

Sung Kang, Non-member (Kyoto University)

It is expected that, in near future, a technology of renewable energy utilization and an electric storage battery will be introduced into the conventional electric power system.

In this study, assuming that a photovoltaic power generation system ( $P V$ system) is installed into the electric power system with a storage battery, the impacts of uncertain variation characteristics of the PV system output on the operations of the conventional power generation system and the storage battery are evaluated by simulations, mainly from the viewpoint of economics. According to the results of simulations, it is clearly demonstrated that economic effects of the $P V$ system are influenced sharply by the forecast accuracy of its output.

キーワード：太陽光発電システム，電力貯蔵装置，修正電力負荷，日間経済運用，予測精度

\section{1.はじめに}

近年, 電力システムにおいては電源の多様化指向お よび地球温暖化などの環境問題の対応のために，自然 エホルギ一の有効利用への関心が高まりつつある。ま た一方では，空調負荷の増大による年負荷率の低下. そして, 源子力発電などの真荷追従特性の悪い電源の 増加という問題を抱えている。このような状況から， 近い将来, 電力貯藏装置や太陽光発電 (以下, $P V$ と 略記）システムなどが大規模に導入されることが予想 される。しかし， $P V$ システムの出力はたとえ 1 時間 前でも正確な予测が困難であり，そのような $P V$ シ ステムが導入されると等洒的に系統負荷の予測誤差が 増え, 既存電源㧈よび電力貯蔵㳖置の経済運用に大き な影響を与えることになる。このような系統負荷の不 確実な変動特性に対する経済性評洒を試みた例は少な
い(1) そこで, 本研究では, $P V$ 出力の予測愦差が特 に電力貯蔵装置の運用に及ぼす影䍌を定量的に評価す る手法を提案すると共に，適当な仮定の下でのシミュ レーションを通してPVシステムの出力の予㑚誤差 とその経済性との関係を罧体的に分析する。

\section{2. 水平面全天日射量に基つく $P V$ 出力の推定}

$P V$ システムには種々の利用形態が考えられるが, 本研究では一般住宅の屋根に設置する小規模分散配置 形で，太陽の追尾を行わないシステムを想定する。た だし，系統への逆潮流は許されるものと仮定し，PV システムの総発電出力に対する経済性評価を行うこと とする。さて，PV出力は，基本的にはそのときの太 陽電池アレイの表面に扔ける傾斜面全天日射量によっ

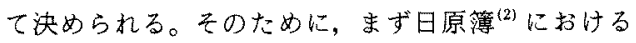
水平面全天日射量を，「永田の式」(3)を用いて直達成

電学碖C, 111 巻 3 号, 平成 3 年 
分と天空散乱成分とに分䧿する（植散分離）。そして, その二つの值により，傾斜面全天日射量を求める(3)。 たたしこの「永田の式」は水平面全天日射量の多い 日に近似度が高くなる式であり，譬り日のように水平 面全天日射量の少ないときははの直散分離が困難な のて，その利用には若干の工夫が必要となる。ここで はそのような場合には，水平面全天日射量をすべて水 平面天空散乱日射量とみなして，傾斜面全天日射量を 推定する。これは， $P V$ システムの低出力時には，そ の出力の推定精度が多少悪くても，PVシステムの経 済性評価に与える影響は小さいと考えられるからで ある。

さて，太晹電池アレイは，す心゙て方位角 $37^{\circ}$, 傾斜 角 $35^{\circ}$ の方向に固定されているものとする。この方向 は，1983 年の大阪の日射量データに基づき，夏季の 14〜15 時の $P V$ 出力が多くなるように求めたもので ある(3)。これは，特に，電力の負荷平準化を念頭にお いたものである。また，直交変換による損失を $20 \%$ ，太陽電池の少化などに伴う賣失を $10 \%$ と仮定 す。

\section{3. $P V$ システムの経済性評洒手法とシミュレ ーションの分析のための仮定}

〈3.1〉経済性評価手法の概要 従来形電源抢よ び電力貯蔵装置からなる電力系統に導入される $P V$ システムの経済性評洒手法について述べる。

さて, 電力眝蔵装置の日間運用手法としては一般 に，増份燃料費の安い軽負荷時間帯に充電し，その工 ネルギーを増分燃料費の高い重負荷時間帯に放電する という経済運用手法が播用されるが，充電および放電 を行うときには，その時刻以降の毎時の電力負荷抢上 び $P V$ 出力の子測值に基づいて運用計画が作成され る。そのため， $P V$ 出力の予測誴差が大きくなると, 電力貯蔵装置による負荷平準化の効果が小さくなり, 電力系統の設備コスト，運転コストの堌大が予想され る。すなわち，PV出力に予測愦差があると仮定した 場合の $P V$ システムの経済性は， $P V$ 出力が完全に 予測できると仮定した場合の経済性よりも悪化すると 推眮される。

本評価手法は，この二つの場合のPVシステムの ブレークイーブン・コスト（以下，BEC と略記）を比 較するためのものである。以下では簡単のため電力負 荷は完全に予測できると仮定する。ただし，電力負荷 の予測譟差を含めても以下に述べる手法は適用でき る。更に，修正電力角荷（=電力負荷 $-P V$ 出力）の 年負荷持続曲線に関しても，適当な精度で予测可能で
あると仮定する。これは，後に述べるように電力詝蔵 装置の運転ルールを決めるためのものである。な扝， 以下で (修正) 電力負荷とは，電力貯蔵装置の運用を 考慮しない值を示すものとし，電力貯蔵装置運用後の 電源にかかる負荷を示す場合には，改めてその旨を明 記する。以下に本論文で提案する評価手法の概要を 示寸。

【ステップ1〕修正電力負荷の年負荷持続曲線を 用いて電力貯蔵装置の運用ルールを定める。

(ステップ2) ある1日の電力貯蔵装置の運用計 画を作成するために，その日の毎時のPV 出力を前 日に予剆し，修正電力負荷を求める。

〔ステップ 3〕求められた修正電力負荷に基づい て, 電力貯蔵装置の経済運用計画を前日に作成する。 ここで，(ステップ1)で作成された運用ルールが用い られる。そして，その計画で必要とされる電力量を， 前日の夜からその日の明け方にかけて充電する。

(ステップ 4) 当日の各時刻において，その時刻 以降のPV 出力の予測值が更新されるため, 〔ステッ プ 3 〕で作成した電力貯蔵装置の放電計画を修正し, 実行する。

[ステップ 5] 1 年を通して[ステップ2〜4]の シミュレーションを行い，その結果より電力貯蔵装置 の運用後の年負荷持続曲線を作成する。

[ステップ6]得られた年負荷持続曲線と各電源 の年費用曲線を用いて最適電源構成を行い，年間の総 発電費用を算出する。

(ステップ7) PVシステムを導入しない場合に ついても上記と同様の計算を行い, 年間の総発電費用 を算出する。この費用と[ステップ 6]で求めた費用と の差より， $P V$ システムの $\mathrm{BEC}$ が計算できる。

次節以降で, 各ステップの詳細と, 具体的なシミュ レーション分析に用いた仮定について述べる。

〈3.2〉電力貯蔵装置の日間運用語十画 ここでは, 修正電力負荷の前日の予測值に基づいて 1 日の電力貯 蔵装置の経済運用計画を作成する([ステップ 1〜3]) ための手法について述べる。

ここで，簡のため次のような仮定を設ける。

（1）電力貯藏装置の容量(充電可能量 $(\mathrm{kW} / \mathrm{h}$ )) に のみ制約を設け，毎時最大放電量には制的を設け ない。

（2）電力貯藏装置の自己放電率は無視する。ま た，その充放電効率は，電力販蔵装置の運転状態によ らず一定值（ともに $90 \%$ ）とする。

（3）電力貯藏装置の運用計画は，（1）式で表され る発電費用低減化の経済性成立条件を満たすように 
表 1 各電源の費用特性

Table 1. Economic parameters of power plants.

\begin{tabular}{|c|c|c|}
\hline 電源種別 & $\begin{array}{c}\text { 固定筫 } \\
(\mathrm{P} / \mathrm{kW} \cdot \mathrm{k} \text { 年 })\end{array}$ & $\begin{array}{c}\text { 可烈算 } \\
(\mathrm{P} / \mathrm{kW} / \mathrm{h})\end{array}$ \\
\hline$\alpha-x$ & 65,000 & 5 \\
\hline ミドル1 & 45,000 & 8 \\
\hline ミドル2 & 35,000 & 15 \\
\hline 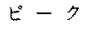 & 25,000 & 40 \\
\hline
\end{tabular}

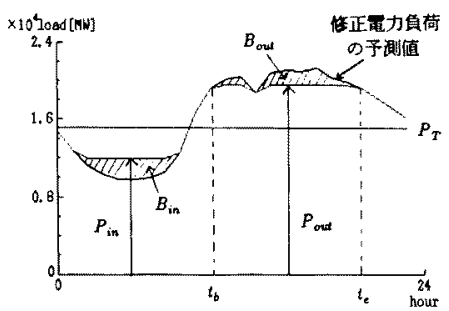

図 1 電力貯蔵装置の充放電量の决定

Fig. 1. Daily operating scheme of the battery.

する。

$\lambda_{\text {in }} / \lambda_{\text {out }} \leq \eta_{\text {in }} \eta_{\text {out }}$

ただし， $\lambda_{\text {In }}\left(\lambda_{\text {out }}\right):$ 充電（放電）時間带での

発電に招ける增分燃料費， $\eta_{\mathrm{In}}\left(\eta_{\mathrm{out}}\right)$ ：充電 (放電) 効率

ここで, 電力供給電源としてはベース, ミドル 1, ミドル 2 およびピーク用の 4 種類の電源を想定する。 その費用特性を表 1 に示寸。そして，電力貯蔵装置の 運用ルールは，充電はベース電源およびミドル 1 電源 のみが発電している時間帯に行い，放電はピーク電源 およびミドル 2 電源が発電している時間帯に行うこと となるものとする。つまり，ベース電源とミドル 1 電 源の容量の和を $P_{T}$ とすると, 日間ピーク負荷が $P_{T}$ を下回ると予測される場合には前夜の充電㹥行わず， さもなければ以下の方法で前夜の充電量を決める。

図 1 において, $P_{\mathrm{ln}}, P_{\text {out }}$ は電力貯蔵装置運転時の電 源にかかる負荷レベル， $B_{\mathrm{in}}$ が1日あたりの充電に利 用される電力量 $(\mathrm{kW} / \mathrm{h}) ， B_{\text {out }}$ が日中の放電によって まかなわ机る電力量 $(\mathrm{kW} / \mathrm{h})$ を示す。そして $B_{\mathrm{in}}$ の 值は,

$P_{\text {in }} \leq P_{T}, P_{\text {out }} \geq P_{T}, B_{\text {out }}=B_{\text {in }} \eta_{\text {in }} \eta_{\text {out }}$

$B_{\mathrm{ln}} \eta_{\mathrm{ln}} \leq$ (電力唄藏装置の容量)

の制約下で最大となるように決定される。〔ステップ 1了は，このP P の值を決めることを意味する。なお， この $P_{T}$ の值は，電力眝藏装置を運転した場合の負荷 持続曲線（電力貯藏装置を負荷側に考えた場合）に対
して求めても同じ值となる。また，放電の開始および 終了時刻を $t_{b}$ 㧍よび $t_{e}$ とする。この值は後に再び利 用される。

後のシミニレーションでは, 修正電力負荷の予測に 用いられる毎時の $P V$ 出力の前日における予測值と して, 毎時の $P V$ 出力の各月に扔ける平均值を用い た。この点については, より精度の高い予測手法が利 用できればそそれに置き換えればよい。

〈3・3〉更新された修正電力負荷の予測值に基つくく 電力貯蔵装置の日間経济運用 前節で述べた手法に より作成された運用計画では，ある時刻の修正電力負 荷の予測值は，通常，誤差を含むものであり，またそ の誤差は，予測を行う時刻との間隔が短くなるにつ れ，一般に減少するものである。そこで，各時刻にお ける放電量は，少なくとも各時刻に扔ける修正電力負 荷の予測值に基づいて決定されなければならない。こ の問題は，厳密にはダイナミックプログラミングの手 法を用いて解かれるが，をれには膨大な計算量を必要 とするため，ここでは簡単のため，以下に述べる七。 ーリスティックな手法を用いることとする。この手法 を定式化すると以下のようになる。

まず，各変数を次のように定義する。

$Z(t)$ : 第 $t$ 時間带に招ける修正電力負荷の実 績值

$Z_{f}(t)$ : 第 $t$ 時間帯における修正電力負荷の前日 において予測した值

$Z_{f}^{\prime}\left(t \mid t_{0}\right)$ : 第 $t_{0}$ 時問帯初めにおいて予測した第 $t$ 時間鱼の修正電力負荷の予測值 $\left(t \geq t_{0}\right)$

$W(t)$ : 第 $t$ 時間带における修正電力負荷の前日 の予測值と実績伹との差 $\left\{Z_{f}(t)-Z(t)\right\}$

$B(t)$ : 第 $t$ 時間帯初めの総放電可能量

$t_{b}:$ 放電開始時刻 (図 1 参照)

$t_{e}:$ 放電終了時刻 (図 1 参照)

$P_{p}$ : 放電時間带に扝计る電力貯藏装置運用後の ピーク負荷の前日の計画値（図 1 の $P_{\text {out }}$ ）

$P(t)$ : 当日の放電時間帯の第 $t$ 時間带における 電力貯蔵装置運用後の電力負荷 $\left(Z_{f}^{\prime}(t \mid t)\right.$ - $P(t)$ が害放電量となる

$r_{1}, r_{2}: P V$ 出力の予測詔差に関する利用可能な 情報量の割合 $\left(0 \leq r_{1}, r_{2} \leq 1 \quad\right.$ (2) 式参照) このとき，修正電力負荷の予測精度を $r_{1}$ と $r_{2}$ の值て 表し,この条件下で, 当日の第 $t$ 時間带における電源 に対する電力負荷 $P(t)$ を順次求める。

まず, $t=t_{b}$ に扔いて $P\left(t_{b}\right)$ の值を以下の上うにし て決める。ここで $t=t_{b} に$ にいて予測された修正電力 負荷 $Z_{f}^{\prime}\left(t \mid t_{b}\right)$ は, 


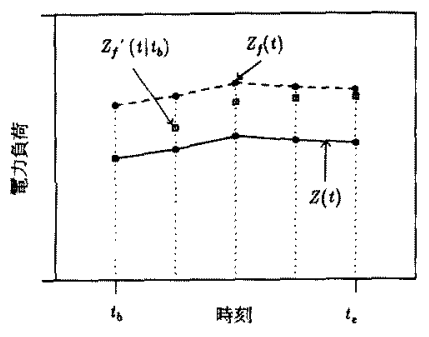

図 2 時刻 $t_{b}$ にお る修正電力萯荷の予測

Fig. 2. Forecast of the modified load.

$$
\left.\begin{array}{c}
Z_{f}^{\prime}\left(t_{b} \mid t_{b}\right)=Z_{f}\left(t_{b}\right)-r_{1} W\left(t_{b}\right) \\
Z_{f}^{\prime}\left(t_{b}+1 \mid t_{b}\right)=Z_{f}\left(t_{b}+1\right)-r_{1} r_{2} W\left(t_{b}+1\right) \\
\vdots \\
Z_{f}^{\prime}\left(t_{b}+n \mid t_{b}\right)=Z_{f}\left(t_{b}+n\right)-r_{1} r_{2}^{n} \cdot W\left(t_{b}+n\right) \\
\vdots \\
Z_{f}^{\prime}\left(t_{e} \mid t_{b}\right)=Z_{f}\left(t_{e}\right)-r_{1} r_{2}^{t_{e}-t_{b}} W\left(t_{e}\right)
\end{array}\right\}
$$

により得られものとする。 $r_{1}, r_{2}$ の值が 1 に近づくと， 予測精度が高くなることを意味する。この仮定㹥恣意 的なものであるが，图 2 からわかるように，予測した 時刻より離れた時刻の予測ほど精度は低下し，前日に おける予測值よりは精度が向上するという荐えを反映 している。他の予測手法が利用でる場合はそれに置 き猷えてシミムレーションを行えばよい。

さてこのとき， $t=t_{b}$ における予測值に基づいて， 電力貯藏装置運用後のピーク負荷が最小となるょうに 運用すれば， $P\left(t_{b}\right)$ ，総放電可能量 $B\left(t_{b}\right)$ 抢よび前日 の計画における負荷レベル $P p$ の間には次の関係が成 立する。

$$
\begin{aligned}
B\left(t_{b}\right) & =\sum_{t=t_{b}}^{t_{e}}\left\{Z_{f}(t)-P_{p}\right\} \\
& =\sum_{t=t_{b}}^{t_{e}}\left\{Z_{f}^{\prime}\left(t \mid t_{b}\right)-P\left(t_{b}\right)\right\}
\end{aligned}
$$

この $(2) ，(3)$ 式から $P\left(t_{b}\right)$ は次のように得られる。

$$
P\left(t_{b}\right)=P_{p}-\frac{r_{1}}{t_{e}-t_{b}+1} \sum_{t=t_{b}}^{t_{e}} r_{2}^{t-t_{b}} W(t) \cdots(4)
$$

次に, $t=t_{b}+1$ において $P\left(t_{b}+1\right)$ の值を決める。す なわち,

$$
\left.\begin{array}{c}
Z_{f}^{\prime}\left(t_{b}+1 \mid t_{b}+1\right)=Z_{f}\left(t_{b}+1\right)-r_{1} W\left(t_{b}+1\right) \\
Z_{f}^{\prime}\left(t_{b}+2 \mid t_{b}+1\right)=Z_{f}\left(t_{b}+2\right)-r_{1} r_{2} W\left(t_{b}+2\right) \\
\vdots \\
Z_{f}^{\prime}\left(t_{b}+n \mid t_{b}+1\right)=Z_{f}\left(t_{b}+n\right)-r_{1} r_{2}^{n-1} W\left(t_{b}+n\right) \\
\vdots \\
Z_{f}^{\prime}\left(t_{e} \mid t_{b}+1\right)=Z_{f}\left(t_{e}\right)-r_{1} r_{2}^{t_{e}-\left(t_{b}+1\right)} W\left(t_{e}\right)
\end{array}\right\}
$$

$$
\begin{aligned}
& B\left(t_{b}+1\right)= \\
& B\left(t_{b}\right)-\left\{Z_{f}^{\prime}\left(t_{b} \mid t_{b}\right)-P\left(t_{b}\right)\right\} \\
& B\left(t_{b}+1\right)=\sum_{t=t_{b}+1}^{t_{b}}\left\{Z_{f}^{\prime}\left(t \mid t_{b}+1\right)-P\left(t_{b}+1\right)\right\}
\end{aligned}
$$

より $P\left(t_{b}+1\right)$ 次次のように得られる。

$$
\begin{aligned}
P\left(t_{b}+1\right)= & \frac{1}{t_{e}-t_{b}}\left[\left(t_{e}-t_{b}+1\right) P_{p}-P\left(t_{b}\right)\right. \\
& -r_{1}\left\{W\left(t_{b}\right)+W\left(t_{b}+1\right)\right. \\
& \left.\left.+\sum_{t=t_{b}+2}^{t_{c}} r_{2}^{t-\left(t_{b}+1\right)} W(t)\right\}\right] \cdots \cdots(8)
\end{aligned}
$$

他の時間帯の場合も同様にして求められる。

\section{4. シミュレーション結果とその考察}

近畿地方に括访る1時間ごとの電力負荷と水平面全 天日射量の複数年（1981～1986年）にわたる実續值 を用いてシミュレーションを行った結果について述ぺ る。な㧍, 電力負荷については過去 6 年間の毎時の実 績值から年トレンドを除去し, 1985 年並みの值にし たデー夕を使用した ${ }^{(3)}$ 。

〈4・1〉 出力が完全に予測できる場合の $P V$ システ ムの経済性評価 まず, $P V$ 出力が完全に予測でき るとした場合に, 電力貯蔵装置の運用が $P V$ システ ムの経済性に及浑す影響について検討する。

図3には電力貯藏装置の日間経済運用を行った後の 日負荷曲線の一例を示す。さて，PVシステムの導入 前㧍よび導入後の日負荷曲線に対して電力貯蔵装置を 前節で述べた手法により運用し，その結果得られる 各々の年負荷持続曲線に基づいて $P V$ システムの $\mathrm{BEC}$ を求めた結果を図 4 に示す。ここで, $P V$ シス テムの総容量については，1,500，3,000，4,500 および $6,000 \mathrm{MWp} の 4$ 種類の場合を, また, 電力貯蔵装置 の総容量については，10,000，20,000および 30,000 MWh 03 種類の場合を想定して計算した。例えば $P V シ ス テ ム の$ 総容量が $3,000 \mathrm{MWp}$ というのは，3 $\mathrm{kWp}$ (表面積約 $30 \mathrm{~m}^{2}$ ) の $P V$ システムを 100 万户 (大阪附の一戸建住宅数に相当) に設置したことに相 当する。またそのときの太陽光発電システムの容量 洒值の変化の様子を図 5 に示す。ここで，PVシステ ムの容量価值とは， $P V$ システムの導入により代替さ れる従来形電源の総容量を意味する。

これらの結果から次のことがわかる。

(1) $P V$ システムの導入規模が小さい場合には, 電力貯藏装置の運用によってピーク負荷が削減され， その結果 $P V$ システムの容量洒值が減り 天の経済性 は低下する。これは，PVシステムが電力貯藏装置と 


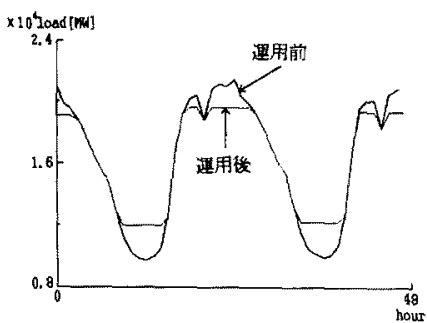

図 3 電力貯蔵装犆運用による日負荷曲線の 変化 (予測誤差なし)

Fig. 3. Daily load curve modified by the operations of batteries (no forecast error).

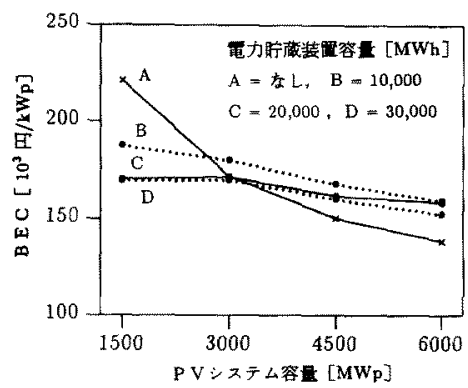

図 $4 P V$ システムの $\mathrm{BEC}$ の変化

Fig. 4. Variation of break-even cost of the PV system.

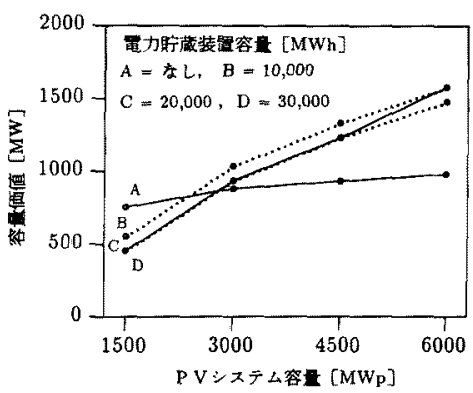

図 $5 P V$ システムの容量洒佔の変化

Fig. 5. Variation of capacity credit of the $P V$ system.

は競合関係にあることを示すものである。

(2)一方， $P V シ$ シテムの導入規模が大きくなり その出力の不規則変動成分が多くなると, 電力貯蔵装 置の運用によってその不規則変動成分がある程度吸収 され，PVシステムの経済性が向上する。このように， $P V シ ス テ ム の$ 導入量によって電力貯蔵装䈌の $P V$ シ ステムの経済性に及ぼす効果が変化することは大変興

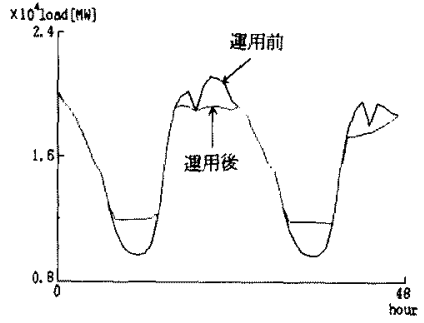

図 6 電力貯蔵装置運用による日負荷曲線の 変化 (予湘器差あり)

Fig. 6. Daily load curve modified by the operations of batteries(with forecast error).

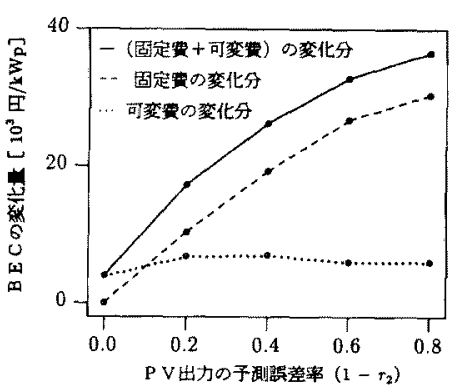

図 $7 P V$ システムの出力の予測誤差率と BEC $の$ 変化量との関係

Fig. 7. Variation of break-even cost of the $P V$ system with the forecast accuracy of its output.

昧深い。

〈4・2〉 $\boldsymbol{P V}$ 出力の予測得差の経済的評価ここてて は，〈3・3〉節で述べた $P V$ 出力の予测誤美に関する利 用可能な情報量の割合 $r_{2}$ の值を変化させることによ D，PVシステムの BEC がどのように変化するかを 調べる。ただし， 導入量は 3,000 MWp の場合についてのみ検討する。

まず，〈3・3〉節で述べた手法に従って電力貯蔵装置 を運用した場合に得られた日負荷曲線の一例を，図 6 に示す。同図上り，負荷の予测誤差により負荷平準化 が妨げられていることが見られる。

次に, $P V$ 出力の予測誤差率と $P V シ ス テ ム の$ BEC の変化量との関係を図 7 実線で示す。ここで, BECの変化量というのは, $P V$ 出力が完全に予測で きるとした場合と予測誤差が存在する場合における BECの差である。この図から，PV出力の予测精度 が $P V$ システムの経済性に大きな影響を与えること が理解される。また，その $\mathrm{BEC} の$ 变化量の内訳を， 
従来形電源の固定費の変化分と可変費の変化分とに分 けて，同じく図 7 にそれぞれ破線と点線で示す。この 図より, $P V$ 出力の予測詰差が増加すると従来形電源 の固定費は比例して増加するが，可変費はほとんど変 化しないことがわかる。これより， BECの変化のほ とんどが, 発電の固定費の増加によるものであること が示される。この図において，当日に更新された $P V$ 出力の予測誤差率 $\left(1-r_{2}\right)$ が 0 の場合に BEC が変化す るのは, $P V$ 出力の前日における予測誤差によるもの である。この結果は, 1985 年のデータをサンプルデ 一タとして得られたものであるが，その他の年のデー 夕に対しても同様の傾向を示すことが確認されてい る。これから, $P V$ 出力の予測誤差に対する経済性評 価は, 修正電力負荷のピークが発生する日の $P V$ 出 力の予測誤差を推定することにより，ほぼ決定される ことがわかる。

\section{5. 終りに}

本論文では, 従来形電源および電力貯蔵装置により 構成される電力系統に $P V$ システムを導入する場合 を想定し，複数年にわたる電力負荷および日射量の実 績値に基づいてその経済性を検討した。特に $P V$ シ ステムの予測困難な出力変動特性が従来形電源および 電力貯蔵装置の経済運用に及ぼす影響を分析する手法 を提案し，更に，実デー夕を用いて妥当な仮定の下に その影響を評価した。今後, より現実的な予測手法に 対してここで述べた評価法を適用する問題が残されて いる。

(平成 2 年 8 月 24 日受付, 同 3 年 1 月 21 日再受付)

$$
\text { 文献 }
$$

（1）清野・内山：「電力眝蔵装置による負荷追従に関する経済効 果」, 電力経済研究, No. 24, p. 57 (昭 63)

(2) 気象庁: 「地上気象観測日原簿」(昭 56 61)

(3) 姜・喜多・手㙇・西川:「太陽光発電システムの電力系統計 画に及ほす影響の評価」第 6 回エネルギーシステム・経済コ ンファレンス講演論文集, p. 197 (平元)

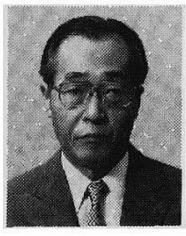

\section{西 川禕 - (正員)}

昭和 8 年 3 月 18 日生。 35 年京都 大学大学院博士課程修了。同大学工 学部助手, 助教授を経て, 47 年教 授, 現在に至る。UCLA 客員助教
授, IIASA 研究所員など歴任。工学博士。システム 制御, 最適化, エネルギーシステム, バイオ・インフォ ーマティクスなどの研究に従事。電子情報通信学会, 計測自動制御学会, システム制御情報学会, エネルギ 一資源学会会員。

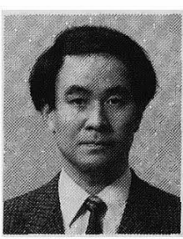

\section{手 塚 哲 央 (正員)}

昭和 58 年東京大学大学院工学系 研究科博士課程 (電気工学専門課 程）修了。同年, 京都大学工学部電 気工学教室助手となり現在に至る。 工学博士。エネルギー需給システムの分析と評価, シ ステムの同定と制御の研究に従事。電気学会, 計測自 動制御学会, システム制御情報学会, エネルギー資源 学会会員。

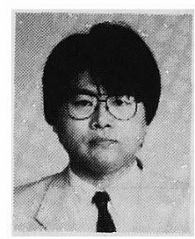

$$
\text { 喜 多一 - (非会員) }
$$

昭和 34 年 11 月 28 日生。 62 年京 都大学博士課程単位修得退学。同年 同大学電気工学第 2 学科助手。 63 年より同大学電気工学科助手, 現在 に至る。エネルギーシステム, バイオ・インフォーマ ティクスの研究に従事。計測自動制御学会, 日本オぺ レーションズ・リサーチ学会会員。

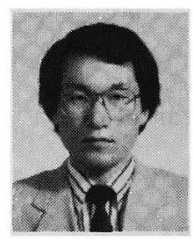

\section{姜 文 盛 (非会員)}

1954 年 12 月 2 日生。1978 年漢陽 大学校工科大学電気工学科卒業(韓 国)。1980 年同大学院電気工学科修 士課程修了。同年, 韓国電力公社入 社。1987 年京都大学大学院工学研究科博士後期課程 入学 (電気工学専攻), 現在に至る。エネルギー需給 システムの分析と評価の研究に従事。 